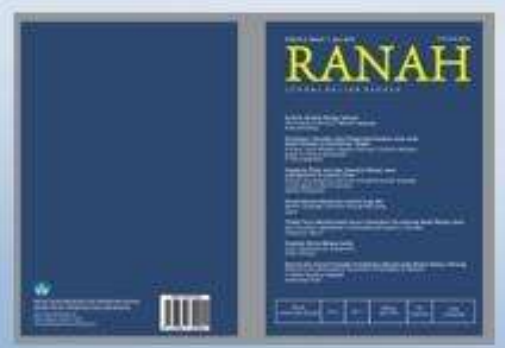

\title{
SERAPAN BAHASA ARAB PADA BUDAYA AKIKAH NI DAGANAK TUBU BERBAHASA ANGKOLA
}

\section{Borrowing Arabic Language on Aqiqah Ni Daganak Tubu in Angkola Language}

\author{
${ }^{1)}$ Husniah Ramadhani Pulungan, ${ }^{2)}$ Suhono, ${ }^{3)}$ Sumarlam \\ 1),3) Universitas Sebelas Maret \\ ${ }^{2)}$ Institut Agama Islam Ma'arif NU Metro Lampung \\ 1),3)husniahpulungan@gmail.com,sumarlamwd@gmail.com \\ ${ }^{2)}$ Suhono120708@gmail.com
}

\begin{abstract}
Abstrak
Penelitian ini menganalisis borrowing bahasa Arab pada bahasa Angkola. Tujuan dari penelitian ini untuk mengklasifikasi proses borrowing bahasa Arab pada bahasa Angkola dari tradisi aqiqah ni daganak tubu. Hal ini dilakukan sebagai salah satu upaya untuk menginventarisasikan pendeskripsian bentuk, kaidah, dan penggunaan borrowing bahasa Arab. Metode penelitian yang digunakan adalah deskriptif kualitatif dengan teknik simak dan catat. Teknik analisis data menggunakan analisis domain, analisis taksonomi, analisis komponensial, dan analisis tema budaya. Hasil analisis menunjukkan bahwa kemunculan adaptasi yang lebih sering dibandingkan dengan kemunculan adopsi sedangkan hibrida dan serapan terjemahan tidak ditemukan. Dengan demikian, maka penggunaan borrowing bahasa Arab dalam acara aqiqah ni daganak tubu tidak menyebabkan terjadinya pergeseran pada bahasa Angkola menjadi kearab-araban, justru borrowing bahasa Arab sangat membantu guna melengkapi leksikon bahasa Angkola khususnya untuk penggunaan istilah keagamaan dalam komunikasi di masyarakat Angkola.
\end{abstract}

Kata kunci: borrowing; bahasa arab; bahasa angkola; aqiqah ni daganak tubu

\section{Abstract}

This study analyzes borrowing on Arabic in Angkola language. The purpose of this study is to classify the process of borrowing Arabic in Angkola language from the tradition of aqiqah, this is the same as the body. It is done as an effort to inventory the description of forms, rules, and use of borrowing Arabic language. This research is descriptive qualitative with the technique refer and note. The data analysis technique uses domain analysis, taxonomic analysis, compound analysis, and analysis of cultural themes. The results show that the emergence of adaptation is more often compared to the emergence of adoption while the hybrid and translation uptake are not found. Thus, the use of borrowing Arabic in the event aqiqah daganak tubu does not cause a shift in the language of Angkola into araba-araban, precisely the borrowing of Arabic is very 
helpful in completing the lexicon of the Angkola language specifically for the use of religious terms in communication in the community.

Keywords: borrowing; arabic; angkola; aqiqah ni daganak tubu

How to Cite: Husniah Ramadhani Pulungan, Suhono, dan Sumarlam. (2019). Serapan Bahasa Arab pada Budaya Akikah Ni Daganak Tubu Berbahasa Angkola. Ranah: Jurnal Kajian Bahasa, 8 (1), 33-52. doi: https://doi.org/10.26499/rnh.v8i1.975

\section{PENDAHULUAN}

Kekayaan indonesia yang melimpah dalam berbagai hal, termasuk kekayaan bahasa daerah merupakan khazanah yang patut dijaga dan dilesatarikan melalui pembelajaran pada aspek linguistik (Sari \& Utama, 2019). Diantaranya keberadaan bahasa daerah, Bahasa Angkola di Kabupaten Tapanuli Selatan Provinsi Sumatra Utara yang memiliki ciri khas tersendiri dalam kegiatan upacara tradisional, seperti kegiatan aqiqah dan upacara pernikahan (Daulay, Islamail R \& Manaf, Abdul M, 2013). Bahasa Angkola merupakan salah satu bahasa yang cenderung mendapatkan pengaruh bahasa Arab dalam leksikonnya. Hal ini terjadi akibat adanya pengaruh penyebaran Islam dalam misi Padri oleh Tuanku Lelo pada tahun 1821 dari Minangkabau (Lubis, 2011) ke wilayah Angkola. Dengan demikian, serapan bahasa Arab cenderung dilakukan untuk melengkapi kosakata yang dibutuhkan dalam kehidupan sehari-hari pada masyarakat Angkola itu sendiri.

Apabila dianalisis beberapa kajian terdahulu, maka dapat ditemukan analisis terkait bahasa serapan sebagai berikut. Penelitian yang relevan dengan penelitian ini di antaranya adalah penelitian (Tadmor, 2007) dengan judul penelitian Grammatical Borrowing in Indonesia. Penelitian ini menjelaskan bahwa pada beberapa kasus bentuk kata plural telah dipinjam dari bahasa Arab. Selain itu pengaruh bahasa asing terhadap bahasa Indonesia dan bahasa daerah berupa peluang atau ancaman (Pastika, 2012); kata serapan bahasa asing dalam Al-qur'an dalam pemikiran At-thobari (Ubaidillah, 2013); perluasan leksikon pada kasus bahasa Arab Yordania (expanding the lexicon: the case of Jordanian Arabic) (Astari, 2014); pembentukan kata dan istilah baru dalam bahasa Arab modern (Sa'aida, 2016); perubahan fonetik pada kata serapan bahasa Arab ke dalam bahasa Jawa dalam bahasa harian (kajian analisis fonologi) (Hadi, 2017); bentuk ortografi istilah serapan bahasa Inggris ke dalam bahasa Arab (Mabruroh, 2017); 
realisasi pronomina dalam bahasa Mooi: analisis tipologi morfologi (Firdaus, 2018); sampai dengan pada pergeseran bahasa daerah pada anak-anak di Kuala Tanjung Sumatra Utara (Sahril, 2018) dan juga analisa mengenai sufiks -is dan sufiks -ik serta problematikanya dalam bahasa Indonesia dapat menjadi acuan peneliti dalam menganalisis proses borrowing bahasa Arab pada bahasa Angkola ((Kulsum, 2015). Berdasarkan beberapa kajian terdahulu tersebut, maka dapat dinyatakan bahwa kajian terkait serapan bahasa Arab pada bahasa Angkola masih terbatas. Oleh karena itu, pada artikel ini akan dipaparkan beberapa analisis terkait serapan bahasa Arab pada bahasa Angkola.

Selanjutnya, mengingat kecenderungan munculnya hal ini terjadi pada peristiwa sosial budaya, maka dipaparkan analisis serapan bahasa Arab terkait dengan salah satu budaya dalam masyarakat Angkola, yaitu pada tradisi akikah. Namun, sebelum dikemukakan lebih lanjut, maka disajikan beberapa kajian terkait dengan akikah sebagai berikut. Dimulai dari tradisi akikah masyarakat Melayu pentas sastra lokal "Syair Nyanyian Anak" dalam kajian etnopuitika, nilai-nilai pendidikan dalam hadits ibadah aqiqah (Sahril, 2014), nilai-nilai pendidikan Islam dalam aqiqah (Al-kusyairi, 2015); nilai-nilai pendidikan Islam dalam pelaksanaan akikah dan tasmiah di Kel. Baamang Hulu Kec. Baamang Kab.Kotim (Mualimin, 2015); Ibm UD. H. Suroto dan Madani aqiqah penyedia hewan kurban (Fitrianor, 2015); penyedia hewan kurban aqiqah dan daging kambing di Purworejo (Rinawidiastuti \& Nursidiq, 2017); sampai dengan prosesi perkawinan Lampung pepadun sebagai bentuk pelestarian bahasa Lampung (Roveneldo, 2017). Penelitian (Tatang dan Syihabuddin, 2014) terkait analisis tuturan direktif dan nilai budaya pada buku al 'arabiyah bayna yadayka pada aqiqah. Sesuai dengan pemaparan di atas, maka dapat dijelaskan bahwa tradisi akikah juga telah dikaji dari berbagai sudut pandang. Akan tetapi, dibutuhkan juga analisis tradisi akikah berdasarkan bahasanya (dalam hal ini dari bahasa serapan yang digunakan). Dengan demikian, berdasarkan hal tersebut, maka dalam artikel ini akan dianalisis serapan bahasa Arab dalam bahasa Angkola yang terdapat pada salah satu tradisi dalam masyarakat Angkola yang dilaksanakan oleh masyarakat Angkola yang dikenal dengan akikah ni daganak tubu. 
Kemudian, apabila ditelusuri mengenai analisis bahasa serapan sebelumnya, maka ditemukan antara lain sebagai berikut. Dimulai dari penemuan mutasi lembut pada verba bahasa Inggris asli meningkat sebagai fungsi kamus pengesahan (listedness), dan frekuensi kejadian, meminjam dan meminjam kata-kata: lemmatizing dari item leksikal yang baru diperoleh dalam bahasa Swedia (borrowing and loan words: the lemmatizing of newly acquired lexical items in sesotho sa leboa), sampai pada penyelidikan perubahan pola komunikasi Muslim Cina untuk mengeksplorasi tingkat integrasi mereka di masyarakat Cina yang mengakibatkan integrasi leksikal dari bahasa ((Poplack, 2012); (Mojela, 2010); (Qurratulain, A., \& Zunnorain, 2015).

Berdasarkan beberapa penelitian di atas, maka penulis melihat bahwa pembahasan serapan bahasa Arab ke dalam bahasa Angkola dapat diteliti sesuai dengan penelitian dan referensi yang relevan sebelumnya. Hal ini bertujuan untuk menginventarisasikan hal-hal yang berkaitan dengan bahasa Angkola dalam kajian morfologi, khususnya proses borrowing dan fitur-fitur semantik yang menyebabkan hal itu terjadi. Penelitian ini bertujuan untuk mendeskripsikan bentuk borrowing bahasa Arab dalam aqiqah ni daganak tubu bahasa Angkola, mendeskripsikan kaidah borrowing bahasa Arab dalam aqiqah ni daganak tubu bahasa Angkola, dan mendeskripsikan apakah penggunaan borrowing bahasa Arab dalam aqiqah ni daganak tubu menyebabkan terjadinya pergeseran pada bahasa Angkola. Dengan demikian ditemukan pola kaidah borrowing bahasa Arab pada bahasa Angkola yang juga berperan dalam pengembangan kebudayaan Angkola itu sendiri.

\section{LANDASAN TEORI}

\section{Borrowing (Serapan)}

Proses penyerapan dalam bahasa Indonesia menurut (Arifin, 2010) terdiri dari empat bagian sebagai berikut:

a. Adopsi adalah serapan utuh tanpa perubahan atau penyesuaian. Unsur-unsur bahasa itu diserap sama dengan bentuk aslinya.

Contoh:

Serapan Bentuk Asli Kata Lain

dawet dhawet dawat

ruwet ruwet ruwat 
b. Adaptasi adalah serapan yang disesuaikan dengan kaidah bahasa Indonesia, yang meliputi kaidah ejaan, pembentukan kata, dan kalimat. Penyesuaian ini dilakukan dengan tujuan untuk membina, menumbuhkan, dan mengembangkan bahasa Indonesia.

Contoh:

Bahasa Jawa Bahasa Indonesia trampil terampil kripik keripik

c. Penghibridaan merupakan penyepadanan dari unsur asing ke unsur bahasa Indonesia. Contoh:

$\begin{array}{lll}\text { Dasar } & \text { Imbuhan } & \text { Hibrida } \\ \text { Asing } & \text { Indonesia } & \text { penstandaran } \\ \text { Indonesia } & \text { Asing } & \text { sengonisasi }\end{array}$

Kemudian, contoh katanya adalah:

modernisasi pemodernan

legalisasi pelegalan

d. Serapan terjemahan yaitu serapan yang dihasilkan dengan menerjemahkan kata/istilah asing tanpa mengubah konsep maknanya. Contoh:

1) Terjemahan langsung, misalnya: upgrading 'penataran'

2) Terjemahan dari serapan adopsi, misalnya: editorial 'tajuk rencana'

3) Terjemahan dari serapan adaptasi, misalnya: deskripsi 'perian'

4) Terjemahan dari serapan hibrida, misalnya: mengedit 'menyunting'

\section{Bahasa Arab}

Bahasa Arab merupakan bahasa agama sekaligus bahasa untuk berkomunikasi dewasa ini yang sudah dianggap urgen oleh berbagai pihak (Ubaidillah, 2013). Selain itu, bahasa Arab memiliki peranan penting dalam perkembangan ilmu pengetahuan. Seperti yang dipaparkan oleh (Salim, 2015) bahwa pada zaman Abbasiyah atau pada saat menjelang abad pertengahan, yang memegang peranan penting dalam memelihara dan mengembangkan berbagai macam ilmu pengetahuan dan filsafat Yunani beserta tafsiran penjelasan ataupun karangan asli dari cendikiawan muslim adalah bahasa Arab. Dengan demikian, maka dapat dinyatakan bahwa bahasa Arab memiliki peranan yang 
besar dalam penyebaran ilmu pengetahuan ke berbagai belahan dunia. Bahasa Arab kini menjadi alat komunikasi bagi sekitar seratus juta orang. Bahasa arab adalah bahasa ilmu pengetahuan, budaya, yang ada sejak abad pertengahan. Bahasa ini selama ratusan tahun dijadikan sebagai pemikiran progresif di seluruh wilayah dunia yang beradab. Hal ini terbukti dengan banyaknya karya dalam bidang kedokteran, filsafat, sejarah, astronomi, agama dan geografi pada abad ke 9 dan 12. Yang ditulis dengan bahasa arab. Dulu, bahasa ini juga digunakan oleh orang-orang Kaldea, Hitti, Babilonia, dan Phoenisia meski kini tidak ada lagi (K. Hitti, 2002).. Orang Arab dan orang-orang yang berlisan Arab masih, dan akan tetap ada. Seperti halnya di masa lalu, kini mereka mendiami wilayah geografis paling strategis yang meliputi salah satu jalur perdagangan tersibuk di dunia.

\section{Bahasa Angkola}

Bahasa Angkola selaku salah satu bahasa daerah di Indonesia berfungsi sebagai lambang kebanggaan daerah, lambang identitas daerah, alat perhubungan di dalam keluarga dan masyarakat daerah, sarana pendukung budaya daerah dan bahasa Indonesia, serta pendukung sastra daerah dan sastra Indonesia (Kusuma \& Widayati, 2015). Kemudian, dalam hubungannya dengan fungsi bahasa Indonesia, maka bahasa daerah berfungsi sebagai pendukung bahasa Indonesia, bahasa pengantar pada tingkat permulaan sekolah dasar di daerah tertentu untuk memperlancar pengajaran bahasa Indonesia dan/atau pelajaran lain, serta sumber kebahasaan untuk memperkaya bahasa Indonesia.

Bahasa Angkola salah satu bahasa daerah di Indonesia yang juga merupakan salah satu sub bahasa Batak. Speech community masyarakat Angkola tinggal di sekitar Padangsidimpuan, Sipirok, dan Gunung Tua (Hutahuruk, 1987).

Menurut (Kozok, 2009), rumpun bahasa Batak dapat dilihat pada bagan 3. berikut. 


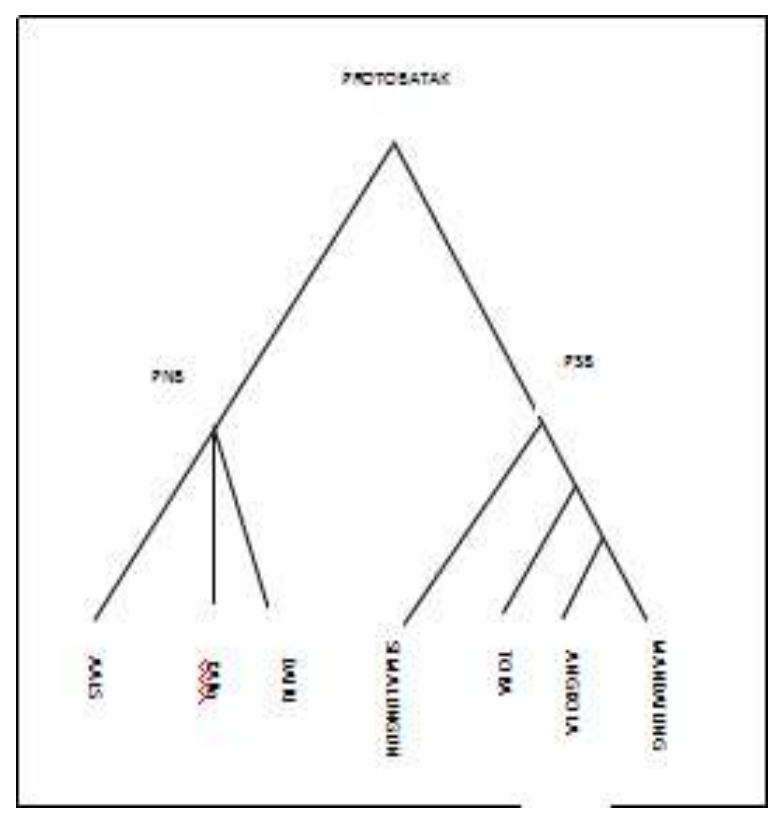

Gambar 2. Rumpun Bahasa Batak

Kelima suku Batak memiliki bahasa yang satu sama lain mempunyai banyak persamaan. Namun demikian, para ahli bahasa membedakan sedikitnya dua cabang bahasa-bahasa Batak yang perbedaannya begitu besar sehingga tidak memungkinkan adanya komunikasi antara kedua kelompok tersebut. Sementara itu, bahasa Angkola, Mandailing, dan Toba membentuk rumpun selatan, sedangkan Karo dan Pakpak-Dairi termasuk rumpun utara. Ahli Bahasa menyatakan bahwa Simalungun acapkali digolongkan sebagai kelompok ketiga yang berdiri di antara rumpun selatan dan utara, namun menurut ahli bahasa Adelaar (dalam (Kozok, 2009), hlm. 13) secara historis bahasa Simalungun ini adalah cabang dari rumpun selatan yang berpisah dari Batak Selatan sebelum bahasa dan bahasa Angkola-Mandailing dan Toba terbentuk.

\section{Aqiqah ni Daganak Tubu}

Masyarakat Angkola masih memegang teguh adat-istiadat yang disandingkan pelaksanaannya dengan agama. Salah satu acara adat yang masih dipertahankan adalah acara adat aqiqah ni daganak tubu. Menurut (Baumi, 2007), hlm. 10-19), ada beberapa langkah persiapan dari acara ini. Persiapan pertama terdiri dari: mengadakan permufakatan di kampung, dihadiri kaum kerabat yang ber-Dalihan Natolu (kahanggianak boru-mora), seperti teman sekampung, dihadiri hatobangon, harajaon, orang 
kaya, dan dihadiri kaum kerabat teman sekampung, demikian juga kaum kerabat masing-masing. Persiapan kedua terdiri dari: pihak yang berbicara (Suhut, Kahanggi, Hombar Suhut, Anak Boru, Pisang Rahut, dan Mora), sedangkan pihak yang menjawab (Hatobangon, Alim Ulama, Pemerintahan, Harajaon, Orang Kaya, dan Raja Pamusuk Huta). Kalau upacara agama dalam bermufakat, tidak perlu menyuguhkan sirih di persidangan, kecuali masyarakat menganjurkan. Selanjutnya, persiapan ketiga terdiri dari: kata-kata di persidangan oleh Suhut, Kahanggi, Hombar Suhut, Anak Boru, Pisang Rahut, dan Mora. Kemudian dijawab oleh Hatobangon, Alim Ulama, Pemerintah, Harajaon, Orang Kaya, Raja Pamusuk/Ompui.

Selanjutnya, dilaksanakan pelaksanaan aqiqah mencukur rambut dan menabalkan nama dengan pelaksanaan sebagai berikut. Pelaksanaan pertama, mencukur rambut dan menabalkan nama. Pelaksanaan kedua, dilanjutkan dengan pembacaan ayat suci Al-Qu'ran, mulai dari Al-Fatihah, takhtim, tahlil, diakhiri dengan doa keberkatan untuk nama anak, aqiqah, dan amal bersama. Pelaksanaan ketiga, ada yang membuat acara mengayun anak, ada yang memanggil ustadz untuk memberikan ceramah agama guna membina anak yang saleh. Pelaksanaan keempat, makan bersama menikmati acara aqiqah, kemudian ditutup dengan memberikan tanda terima kasih dari suhut. Zaman sekarang pada umumnya menyandingkan adat dengan agama. Demikianlah, acara pelaksanaan aqiqah, mencukur rambut, dan menabalkan nama anak. Adat mempererat hubungan keluarga, agama menuntun ke jalan rida Allah.

\section{METODE PENELITIAN}

Jenis penelitian ini adalah deskriptif kualitatif. Lokasi berupa dokumen tertulis (buku) yang mendeskripsikan nilai-nilai budaya masyarakat Angkola. Nilai-nilai yang diinterpretasikan dari dokumen tersebut akan dapat terlihat pada borrowing bahasa Arab yang digunakan oleh penulis dokumen tersebut. Sumber data penelitian ini adalah Buku Burangir Barita yang terbit pada tahun 2007 yang memuat petunjuk cara pelaksanaan horja dan mangkobar dalam upacara adat hombar adat dohot ibadat, yang salah satunya adalah Aqiqah ni Daganak Tubu. Datanya berupa borrowing bahasa Arab dengan empat proses pengumpulan, yaitu: adopsi, adaptasi, penghibridaan, dan serapan terjemahan dalam acara adat aqiqah ni daganak tubu. Hal ini sesuai dengan pernyataan (Santosa, 2014), hlm. 51) yang mendeskripsikan bahwa sumber data merupakan sumber 
dari mana data itu diperoleh. Di dalam penelitian sumber data dapat berupa tempat, informan, kejadian, dokumen, situs, dan sebagainya. Tidak semua penelitian menggunakan sumber data sebanyak itu. Banyak dan sedikitnya sumber data tergantung pada kompleksitas fokus penelitiannya. Data untuk analisis dapat berasal dari analisis isi bahan yang ada yaitu transkrip yang terdapat dalam buku Burangir Barita yang terbit tahun 2007. Data ini merupakan data sekunder karena mengambil data yang telah dikumpulkan oleh peneliti lain terdahulu, namun terdapat perbedaan yang signifikan dari proses analisisnya.Teknik sampling yang digunakan adalah berdasarkan tujuan penelitian atau purposive sampling (Santosa, 2014). Teknik pengumpulan data dalam penelitian ini adalah analisis dokumen serta teknik simak dan catat. Teknik analisis data dalam penelitian kali ini akan disajikan dengan empat prosedur, yaitu: analisis domain, analisis taksonomi, analisis komponensial, dan analisis tema budaya. Kemudian masingmasing analisis tersebut akan diberi pemaparan deskripsinya. Pemilihan keempat analisis data ini berdasarkan pemaparan (Santosa, 2014), hlm. 65) bahwa secara umum analisis data induktif kualitatif dapat dibagi menjadi empat tahapan besar yaitu: analisis domain, analisis taksonomi, analisis komponensial, dan analisis tema budaya. Adapun analisis domainnya adalah sebagai berikut:

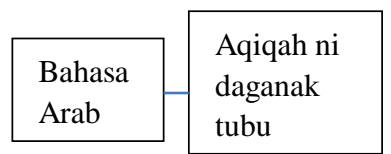

Bagan 1. Analisis Domain

Domainnya adalah bahasa Arab yang akan dianalisis pada konteks acara adat aqiqah ni daganak tubu. Sedangkan analisis taksonominya dapat dilihat pada bagan berikut.

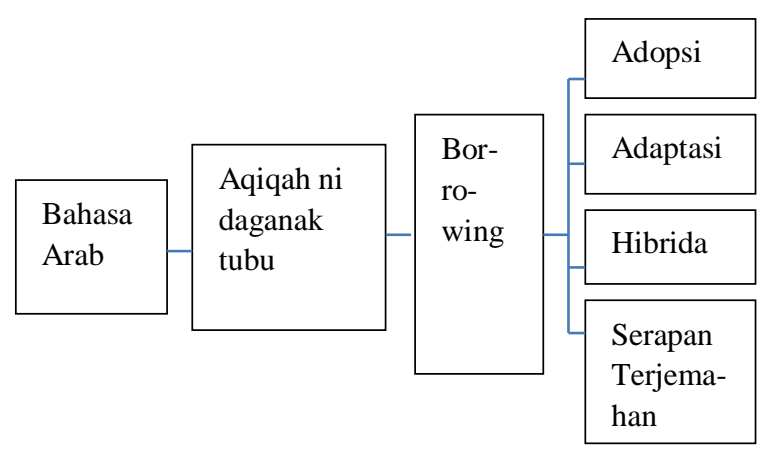

Bagan 2. Analisis Taksonomi 
Melanjutkan analisis domain pada bagan 1. maka dilanjutkan dengan penganalisisan borrowing bahasa Arab tadi pada empat proses, yaitu: adopsi, adaptasi, hibrida, dan serapan terjemahan. Adapun, analisis komponensialnya adalah pada tabel berikut.

Tabel 1

Analisis Komponensial

\begin{tabular}{|c|c|c|c|c|c|c|}
\hline \multirow{2}{*}{$\begin{array}{l}\text { Bahasa } \\
\text { Arab }\end{array}$} & \multicolumn{4}{|c|}{ Borrowing } & \multirow[b]{2}{*}{$\sum$} & \multirow{2}{*}{$\%$} \\
\hline & $\begin{array}{l}\text { Adop- } \\
\text { si }\end{array}$ & $\begin{array}{l}\text { Adap- } \\
\text { tasi }\end{array}$ & $\begin{array}{l}\text { Hib- } \\
\text { Rida }\end{array}$ & $\begin{array}{l}\text { Sera- } \\
\text { pan } \\
\text { Terje- } \\
\text { mahan }\end{array}$ & & \\
\hline \multicolumn{7}{|c|}{$\begin{array}{l}\text { Aqiqah ni daganak } \\
\text { tubu }\end{array}$} \\
\hline Jumlah & & & & & & \\
\hline
\end{tabular}

Berdasarkan tabel 1. di atas, maka pengklasifikasian dan analisis borrowing bahasa Arab yang ditemukan dalam bahasa Angkola lebih mudah untuk dilakukan dan dideskripsikan pada pembahasan.

\section{PEMBAHASAN}

\section{Bentuk Borrowing Bahasa Arab dalam Aqiqah ni Daganak Tubu Bahasa Angkola}

Bentuk borrowing bahasa Arab dalam aqiqah ni daganak tubu yang berbahasa Angkola merupakan pengembangan penelitian dari serapan kosakata bahasa Arab yang mempengaruhi budaya Islam Batak Angkola-Mandailing (Pulungan, 2016). Perbedaannya adalah pada serapan kosakata bahasa Arab yang mempengaruhi budaya Islam Batak Angkola-Mandailing cenderung menganalisis kosakata utuh (kata dasar dan kata jadian), kosakata Arab yang mengalami perubahan (penggantian, penambahan, dan penghilangan fonem), kosakata bahasa Arab yang digunakan dalam bahasa AngkolaMandailing, serta istilah, nama, dan semboyan pada bahasa Arab. Sementara itu, pada serapan bahasa Arab pada budaya aqiqah ni daganak tubu berbahasa Angkola cenderung untuk mendeskripsikan serapan bahasa Arab yang ditemukan pada salah satu tradisi budaya aqiqah yang berbahasa Angkola berdasarkan klasifikasi adopsi, adaptasi, hibrida, dan serapan terjemahan. Dengan demikian, maka dapat dideskripsikan bahwa 
bahasa Arab banyak memberikan sumbangan leksikon dan berintegrasi dengan bahasa Angkola yang menjadi bagian dari budaya masyarakat Angkola.

Berikut adalah data serapan bahasa Arab yang terdapat pada bahasa Angkola dalam tradisi budaya aqiqah ni daganak tubu pada tabel 2. berikut.

Tabel 2

Bentuk Borrowing Bahasa Arab pada bahasa Angkola

\begin{tabular}{|c|c|c|}
\hline Bahasa Arab & $\begin{array}{l}\text { Bahasa } \\
\text { Angkola }\end{array}$ & Keterangan \\
\hline 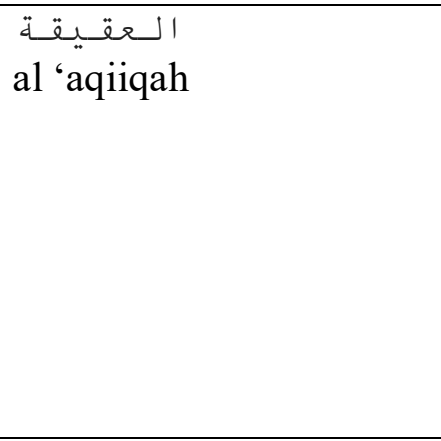 & aqiqah & $\begin{array}{l}\text { akikah } / a k i \cdot k a h / n \text { Isl } 1 \text { penyembelihan } \\
\text { ternak (lembu atau kambing) yang mana } \\
\text { sebagai pernyataan rasa syukur orang tua } \\
\text { setelah kelahiran anaknya, pelaksanaan } \\
\text { acara ini dilaksanakan pada hari ketujuh; } \\
\mathbf{2} \text { tradisi penyembeli-han ternak pada } \\
\text { upacara pencukuran rambut bayi ketika } \\
\text { berusia tujuh hari sebagai pernyataan } \\
\text { syukur. }\end{array}$ \\
\hline حضر hadhara & hadir & hadir/ha.dir/v ada; (ada) datang \\
\hline الــوم alkawm & Koum & $\begin{array}{l}\mathbf{k a u m} / \mathrm{ka} \cdot \mathrm{um} / \mathrm{n} \mathbf{1} \text { suku bangsa; } \mathbf{2} \text { sanak } \\
\text { saudara; kerabat; keluarga; } \mathbf{3} \text { golongan } \\
\text { (orang yang sekerja, sepaham, sepangkat, } \\
\text { dan sebagainya); } \mathbf{4} \text { ark lebai; modin; } \\
\mathbf{5} \text { keluarga garis matrilineal }\end{array}$ \\
\hline $\begin{array}{l}\text { al 'aliim } \\
\text { al }\end{array}$ & Alim & $\begin{array}{l}\text { alim }^{1} \text { a } \mathbf{1} \text { berilmu (terutama dalam hal } \\
\text { agama Islam); } \mathbf{2} \text { saleh }\end{array}$ \\
\hline 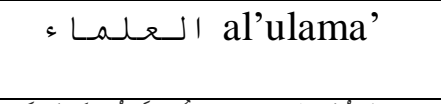 & ulama & $\begin{array}{l}\text { ulama } / \text { ula } \cdot m a / n \text { orang yang ahli dalam } \\
\text { hal atau dalam pengetahuan agama Islam }\end{array}$ \\
\hline 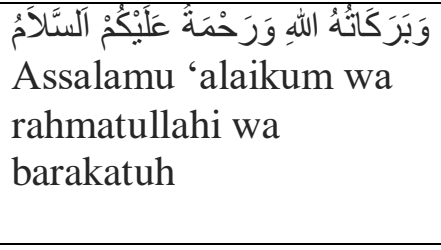 & $\begin{array}{l}\text { Assalamu- } \\
\text { 'alaikum } \\
\text { Warohma- } \\
\text { tullohi } \\
\text { Wabarokatuh }\end{array}$ & $\begin{array}{l}\text { Semoga keselamatan, rahmat Allah dan } \\
\text { berkah-Nya tercurah kepadamu }\end{array}$ \\
\hline شكر shakara & syukur & $\begin{array}{l}\text { syukur/syu } \cdot \text { kur/ } \mathbf{1} n \text { rasa terima kasih } \\
\text { kepada Allah; } \mathbf{2} p \text { untunglah (pernyataan } \\
\text { lega, senang, dan sebagainya) }\end{array}$ \\
\hline $\begin{array}{l}\text { الله سبح وتعالى } \\
\text { Allah subhanahu } \\
\text { wata’alaa }\end{array}$ & Allah swt. & $\begin{array}{l}\text { Allah } n \text { nama Tuhan dalam bahasa Arab; } \\
\text { pencipta alam semesta yang } \\
\text { mahasempurna; Tuhan Yang Maha Esa } \\
\text { yang disembah, } \\
\text { Allah Yang Mahasuci lagi Mahatinggi }\end{array}$ \\
\hline ridho & ridho & $\begin{array}{l}\text { rida } r i \cdot d a / \text { a } \mathbf{1} \text { rela; suka; senang hati; } \\
\mathbf{2} \text { perkenan; rahmat }\end{array}$ \\
\hline akhbaro & hobarki & laporan tentang \\
\hline
\end{tabular}




\begin{tabular}{|c|c|c|}
\hline & $\begin{array}{l}\text { Nomina } \\
\text { Dasar: hobar }\end{array}$ & $\begin{array}{l}\text { peristiwa yang biasanya belum lama } \\
\text { terjadi; berita; warta; berita yang tersebar } \\
\text { biasanya lebih hebat daripada kenyataan } \\
\text { yang sebenarnya }\end{array}$ \\
\hline ashsholawaat الــــــــ ات & salawat & $\begin{array}{l}\text { selawat/se } \cdot l a \cdot \text { wat/ (jamak dari salat) } A r \\
n 1 \text { permohonan kepada Tuhan; } \\
\text { doa: berdoa memohon berkat } \\
\text { Tuhan; } 2 \text { doa kepada Allah untuk Nabi } \\
\text { Muhammad saw. beserta keluarga dan } \\
\text { sahabatnya; }\end{array}$ \\
\hline $\begin{array}{l}\text { رسول الله صلى عليه وسلم } \\
\text { Rasululloh shollallohu } \\
\text { 'alaihi wasallam }\end{array}$ & $\begin{array}{l}\text { Rasulullah } \\
\text { saw. }\end{array}$ & $\begin{array}{l}\text { Rasulullah/Ra.su } \cdot l u l \cdot l a h / n \text { utusan Allah } \\
\text { (Nabi Muhammad saw.) }\end{array}$ \\
\hline 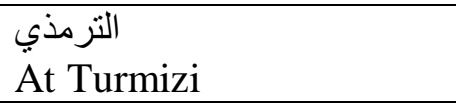 & At Turmizi & Nama Perawi Hadis \\
\hline 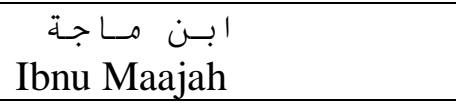 & Ibnu Majah & Nama Perawi Hadis \\
\hline 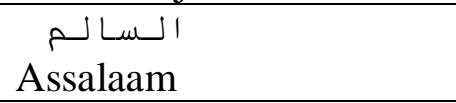 & salam & $\begin{array}{l}\text { salam } 1 / \text { sa } \cdot \text { lam/ } n \mathbf{1} \text { damai; } \mathbf{2} \text { pernya-taan } \\
\text { hormat; tabik; } \mathbf{3} \text { ucapan }\end{array}$ \\
\hline $\begin{array}{l}\text { lillah } \\
\text { lilhamdu- }\end{array}$ & $\begin{array}{l}\text { alhamdulilla } \\
\mathrm{h}\end{array}$ & $\begin{array}{l}\text { alhamdulillah } / \mathrm{al} \cdot \mathrm{ham} \cdot \mathrm{du} \cdot \mathrm{lil} \cdot \mathrm{lah} / \mathrm{p} \\
\text { ungkapan untuk menyatakan rasa syukur } \\
\text { (maknanya 'segala puji bagi Allah') }\end{array}$ \\
\hline الــرحمـة Arrahmah & rahmat & $\begin{array}{l}\text { rahmat } / \text { rah } \cdot \text { mat } / n \text { 1 belakasih; } \\
\text { kerahiman; } \quad \mathbf{2} \text { karunia (Allah); berkah } \\
\text { (Allah) }\end{array}$ \\
\hline & nikmat & $\begin{array}{l}\text { nikmat } / \text { nik } \cdot \text { mat/ } 1 \text { a enak; lezat; } \\
\mathbf{2} \text { a merasa puas; senang; } \mathbf{3} n \text { pemberian } \\
\text { atau karunia (dari Allah) }\end{array}$ \\
\hline ا الـــ عـا ؛ alddu'a' & $\begin{array}{l}\text { mandoahon } \\
\text { Nomina } \\
\text { Dasar: doa }\end{array}$ & $\begin{array}{l}\text { doa } n \text { permoho-nan (harapan, permintaan, } \\
\text { pujian) kepada Tuhan }\end{array}$ \\
\hline صـSholih & sholih & $\begin{array}{l}\text { saleh } 1 \text { /sa·leh// saléh/ a } \mathbf{1} \text { taat dan } \\
\text { sungguh-sungguh menjalankan } \\
\text { ibadah; } 2 \text { suci dan beriman }\end{array}$ \\
\hline حـلال halala & $\begin{array}{l}\text { dihalalkon } \\
\text { Nomina } \\
\text { Dasar: halal }\end{array}$ & $\begin{array}{l}\text { halal /ha.lal / } 1 \text { a diizinkan (tidak dilarang } \\
\text { oleh syarak; } \mathbf{2} a \text { (yang diperoleh atau } \\
\text { diperbuat dengan) sah; } \mathbf{3} \text { ark } n \text { izin; ampun }\end{array}$ \\
\hline Alfatihah الــــــــــة & Al Fatihah & $\begin{array}{l}\text { fatihah } / f a \cdot t i \cdot h a h / n \\
\text { Isl } \mathbf{1} \text { pembukaan; } \mathbf{2} \text { surah Fatihah (dengan } \\
\text { huruf pertamanya kapital) }\end{array}$ \\
\hline attahlil الــتـــــــل & tahlil & $\begin{array}{l}\text { tahlil } 1 / \text { tah.lil/ } n \mathbf{1} \text { Isl pengucapan kalimat } \\
\text { tauhid laa ilaaha illallah 'tidak ada Tuhan } \\
\text { selain Allah' secara berulang-ulang; } \mathbf{2} \text { nya- } \\
\text { nyian pujian }\end{array}$ \\
\hline $\begin{array}{l}\text { آل بـركـات } \\
\text { al barakat }\end{array}$ & $\begin{array}{l}\text { kaborkatan } \\
\text { Nomina }\end{array}$ & $\begin{array}{l}\text { berkat }^{1} / \text { ber } \cdot k a t / 1 \\
\text { membawa kebaikan dalam hidup manusia; }\end{array}$ \\
\hline
\end{tabular}




\begin{tabular}{|c|c|c|}
\hline & $\begin{array}{l}\text { Dasar: } \\
\text { borkat }\end{array}$ & $\begin{array}{l}2 n \text { doa restu dan pengaruh baik (yang } \\
\text { mendatangkan selamat dan bahagia) dari } \\
\text { orang yang dihormati atau dianggap suci } \\
\text { (keramat), seperti orang tua, guru, pemuka } \\
\text { agama; } 3 n \text { makanan dan sebagainya yang } \\
\text { dibawa pulang sehabis kenduri; } \\
\mathbf{4} \text { vcak mendatangkan } \\
\text { bermanfaat; berkah }\end{array}$ \\
\hline astad ' أســــــــ د & ustadz & $\begin{array}{l}\text { ustaz/us.taz/ } A r n \mathbf{1} \text { guru agama atau guru } \\
\text { besar (laki-laki); } \mathbf{2} \text { tuan (sebutan atau } \\
\text { sapaan) }\end{array}$ \\
\hline 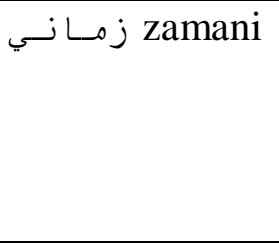 & zaman & $\begin{array}{l}\text { zaman/za.man/ } n \mathbf{1} \text { jangka waktu yang } \\
\text { panjang atau pendek yang menandai } \\
\text { sesuatu; masa; } \mathbf{2} \text { kala; waktu; penghabisan } \\
\text { masa kehidupan kita; sudah tidak sesuai } \\
\text { lagi dengan keadaan; } \mathrm{ki} \text { sudah kuno; kolot; }\end{array}$ \\
\hline
\end{tabular}

Berdasarkan tabel 1 di atas telah ditemukan 26 borrowing bahasa Arab pada bahasa Angkola dalam upacara adat aqiqah ni daganak tubu. Bentuk-bentuk borrowing yang telah ditemukan selanjutnya akan dianalisis secara morfologis termasuk kaidah borrowing seperti apa yang telah dialami oleh leksikon bahasa Angkola tersebut.

\section{Kaidah borrowing bahasa Arab dalam aqiqah ni daganak tubu bahasa Angkola}

Adapun kaidah borrowing bahasa Arab dalam aqiqah ni daganak tubu bahasa Angkola dapat diklasifikasikan sebagai berikut.

1. Adopsi adalah serapan utuh tanpa perubahan atau penyesuaian. Unsur-unsur bahasa itu diserap sama dengan bentuk aslinya sebagai berikut.

Tabel 3

Adopsi

\begin{tabular}{lll}
\hline Bahasa Arab & Bahasa Angkola & Keterangan \\
\hline Allah swt. & Allah swt. & Tetap \\
\hline Rasulullah saw. & Rasulullah saw. & Tetap \\
\hline Alfatihah & Alfatihah & Tetap \\
\hline Alhamdulillah & Alhamdulillah & Tetap \\
\hline $\begin{array}{l}\text { Assalamu'alaikum } \\
\text { warohmatullohi } \\
\text { wabarokatuh }\end{array}$ & $\begin{array}{l}\text { Assalamu'alaikum } \\
\text { warohmatullohi }\end{array}$ & Tetap \\
\hline At-Turmizi & At-Tubarokatuh & \\
\hline Ibnu Majah & Ibnu Majah & Tetap \\
\hline ustadz & Ustadz & Tetap \\
\hline
\end{tabular}


Berdasarkan tabel 3. di atas, maka dapat dijelaskan bahwa nama Tuhan, sebutan untuk Rasul, nama surat Alquran, pujian untuk Allah, ucapan salam, dan nama orang adopsi secara utuh tanpa perubahan sedikitpun.

2. Adaptasi adalah serapan yang disesuaikan dengan kaidah bahasa Angkola, yang meliputi kaidah ejaan, pembentukan kata, dan kalimat. Penyesuaian itu perlu dilakukan dengan tujuan untuk membina, menumbuhkan, dan mengembangkan bahasa Angkola sebagai berikut.

Tabel 4

Adaptasi

\begin{tabular}{|c|c|c|}
\hline Bahasa Arab & Bahasa Angkola & Keterangan \\
\hline al 'aqiiqah & aqiqah & $\begin{array}{l}\text { analisis: } \\
\text { al } \rightarrow \text { hilang } \\
\text { 'a } \rightarrow \text { a } \\
\text { qii } \rightarrow \text { qi } \\
\text { qah } \rightarrow \text { qah } \\
\text { aqiqah }\end{array}$ \\
\hline al kawm & koum & $\begin{array}{l}\text { analisis: } \\
\text { al } \rightarrow \text { hilang } \\
\text { ka } \rightarrow \text { ko } \\
\text { wm } \rightarrow \text { um } \\
\text { koum }\end{array}$ \\
\hline al 'aliim & alim & $\begin{array}{l}\text { analisis: } \\
\text { al } \rightarrow \text { hilang } \\
\text { 'a } \rightarrow \text { a } \\
\lim \rightarrow \lim \\
\text { alim }\end{array}$ \\
\hline al 'ulama' & ulama & $\begin{array}{l}\text { analisis: } \\
\text { al } \rightarrow \text { hilang } \\
\text { 'u } \rightarrow \mathrm{u} \\
\mathrm{la} \rightarrow \mathrm{la} \\
\text { ma' } \rightarrow \text { ma } \\
\text { ulama }\end{array}$ \\
\hline ashsholawat & salawat & $\begin{array}{l}\text { analisis: } \\
\text { ash } \rightarrow \text { hilang } \\
\text { sho } \rightarrow \text { sa } \\
\text { la } \rightarrow \text { la } \\
\text { wat } \rightarrow \text { wat } \\
\text { salawat }\end{array}$ \\
\hline assalam & salam & $\begin{array}{l}\text { analisis: } \\
\text { as } \rightarrow \text { hilang } \\
\text { sa } \rightarrow \text { sa } \\
\text { lam } \rightarrow \text { lam } \\
\text { salam }\end{array}$ \\
\hline
\end{tabular}




\begin{tabular}{|c|c|c|}
\hline arrohmah & rahmat & $\begin{array}{l}\text { analisis: } \\
\text { ar } \rightarrow \text { hilang } \\
\text { roh } \rightarrow \text { rah } \\
\text { mah } \rightarrow \text { mat } \\
\text { rahmat }\end{array}$ \\
\hline at tahlil & tahlil & $\begin{array}{l}\text { analisis: } \\
\text { at } \rightarrow \text { hilang } \\
\text { tah } \rightarrow \text { tah } \\
\text { lil } \rightarrow \text { lil } \\
\text { tahlil }\end{array}$ \\
\hline al barokah & borkat & $\begin{array}{l}\text { analisis: } \\
\text { al } \rightarrow \text { hilang } \\
\text { ba } \rightarrow \text { bo } \\
\text { ro } \rightarrow \text { r } \\
\text { kah } \rightarrow \text { kat } \\
\text { borkat }\end{array}$ \\
\hline hadhara & hadir & $\begin{array}{l}\text { analisis: } \\
\text { ha } \rightarrow \text { ha } \\
\text { dha } \rightarrow \text { di } \\
\text { ra } \rightarrow \text { r } \\
\text { hadir }\end{array}$ \\
\hline shakara & syukur & $\begin{array}{l}\text { analisis: } \\
\text { sha } \rightarrow \mathrm{syu} \\
\mathrm{ka} \rightarrow \mathrm{ku} \\
\mathrm{ra} \rightarrow \mathrm{r} \\
\text { syukur }\end{array}$ \\
\hline akhbaro & hobar & $\begin{array}{l}\text { analisis: } \\
\mathrm{a} \rightarrow \text { hilang } \\
\text { kh } \rightarrow \text { ho } \\
\text { ba } \rightarrow \text { ba } \\
\text { ro } \rightarrow \text { r } \\
\text { hobar }\end{array}$ \\
\hline ridhoo & ridho & $\begin{array}{l}\text { analisis: } \\
\text { ri } \rightarrow \text { ri } \\
\text { dhoo } \rightarrow \text { dho }\end{array}$ \\
\hline shoolih & sholih & $\begin{array}{l}\text { analisis: } \\
\text { shoo } \rightarrow \text { sho } \\
\text { lih } \rightarrow \text { lih } \\
\text { sholih }\end{array}$ \\
\hline zamanii & zaman & $\begin{array}{l}\text { analisis: } \\
\mathrm{za} \rightarrow \mathrm{za} \\
\mathrm{ma} \rightarrow \mathrm{ma} \\
\text { nii } \rightarrow \mathrm{n} \\
\text { zaman }\end{array}$ \\
\hline ad du'aa & doa & $\begin{array}{l}\text { analisis: } \\
\text { ad } \rightarrow \text { hilang }\end{array}$ \\
\hline
\end{tabular}




\begin{tabular}{lll}
\hline & & $\begin{array}{l}\text { du } \rightarrow \text { do } \\
\text { 'aa } \rightarrow \text { a } \\
\text { doa }\end{array}$ \\
\hline ni'mat & nikmat & analisis: \\
& ni' $\rightarrow$ nik \\
& mat $\rightarrow$ mat \\
& nikmat \\
\hline halala & halal & analisis: \\
& & ha $\rightarrow$ ha \\
& la $\rightarrow$ la \\
& la $\rightarrow 1$ \\
& halal \\
\hline
\end{tabular}

Berdasarkan tabel 4 terdapat beberapa pola adaptasi, yaitu: penghilangan al, pengurangan vokal ganda menjadi satu vokal, sh menjadi $s$, $k h$ menjadi $h$, tanda 'ain yang berada pada suku tertutup menjadi $k$, suku kata terbuka, terbuka yang berakhiran vokal $a$ dihilangkan, suku kata tertutup yang diakhiri $h$ menjadi $t$, dan pertemuan huruf vokal yang berbeda $u$ dan $a$ menjadi $o$.

3. Penghibridaan merupakan penyepadanan dari unsur asing ke unsur bahasa Angkola. Namun, dalam analisis kali ini tidak ditemukan proses penghibridaan.

4. Serapan terjemahan yaitu serapan yang dihasilkan dengan menerjemahkan kata/istilah asing tanpa mengubah konsep maknanya. Sama dengan penghibridaan, serapan terjemahan juga tidak ditemukan dalam analisis kali ini.

\section{Penggunaan Borrowing Bahasa Arab dalam Aqiqah ni Daganak Tubu}

Pada realitanya, setelah data dianalisis maka dapat dinyatakan bahwa penggunaan borrowing bahasa Arab dalam aqiqah ni daganak tubu tidak menyebabkan terjadinya pergeseran pada bahasa Angkola. Pergeseran yang dimaksud adalah bahasa Arab tidak mengubah kedudukan bahasa Angkola di dalam masyarakat tetapi bahasa Arab telah memberikan pengaruh yang baik dalam rangka melengkapi kekurangan dan kebutuhan kosakata bahasa Angkola, khususnya yang dengan istilah keagamaan. Kecenderungan kemunculan dan penggunaan borrowing bahasa Arab pada bahasa Angkola terjadi akibat pengaruh dari penyebaran Islam oleh Tuanku Lelo pada misi Padri di 1821 dari Minangkabau (Lubis, 2011). Dengan demikian, mayoritas agama 
yang terdapat di wilayah Angkola adalah agama Islam dan otomatis banyak mendapat pengaruh dari bahasa Arab dalam kehidupan sehari-hari.

Tabel 5

Analisis Komponensial Akhir

\begin{tabular}{|c|c|c|c|c|c|c|}
\hline \multirow{2}{*}{$\begin{array}{l}\text { Bahasa } \\
\text { Arab }\end{array}$} & \multicolumn{4}{|c|}{ Borrowing } & \multirow[b]{2}{*}{$\sum$} & \multirow[b]{2}{*}{$\%$} \\
\hline & $\begin{array}{l}\text { Adop- } \\
\text { si }\end{array}$ & $\begin{array}{l}\text { Adap- } \\
\text { tasi }\end{array}$ & $\begin{array}{l}\text { Hib- } \\
\text { rida }\end{array}$ & $\begin{array}{l}\text { Serapan } \\
\text { Terje- } \\
\text { mahan }\end{array}$ & & \\
\hline $\begin{array}{l}\text { Tradisi } \\
\text { Aqiqah ni } \\
\text { Daganak } \\
\text { Tubu }\end{array}$ & 8 & 18 & 0 & 0 & 26 & 100 \\
\hline Jumlah & 8 & 18 & 0 & 0 & 26 & 100 \\
\hline
\end{tabular}

Sesuai dengan tabel 5. di atas, maka dapat dikemukakan bahwa kata serapan bahasa Arab yang muncul dari tradisi aqiqah ni daganak tubu di atas terdiri dari dua jenis, yaitu: adopsi sebanyak 8 kata dan adaptasi sebanyak 18 kata. Sementara itu, hibrida dan serapan terjemahan tidak ditemukan sama sekali. Kemunculan adopsi sebanyak 8 kata tersebut karena serapan yang dilakukan utuh tanpa perubahan atau penyesuaian seperti pada tabel 3. Di sisi lain, adaptasi merupakan proses serapan yang disesuaikan dengan kaidah bahasa Angkola, yang meliputi kaidah ejaan, pembentukan kata, dan kalimat. Selain itu, adaptasi juga membutuhkan proses penyesuaian pelafalan antara bahasa Arab dengan bahasa Angkola seperti pada tabel 4 di atas. Kemudian, terkait hibrida dan serapan terjemahan tidak ditemukan karena dalam tradisi tersebut belum menggunakan kesepadanan unsur asing lainnya dan terjemahan.

Mengingat, hanya satu konteks yang dianalisis maka dapat dinyatakan bahwa tema budaya yang cenderung ditemukan dalam bahasa Angkola adalah proses borrowing adaptasi yang sangat tinggi karena perbedaan pelafalan yang mencolok. Adopsi hanya untuk penamaan tertentu yang sudah baku. Hibrida dan serapan terjemahan belum ditemukan. Dengan demikian, bahasa Angkola terus mengalami perkembangan dan mengalami proses dalam melengkapi leksikonnya. Masyarakat Angkola menjadi lebih kaya dalam berkomunikasi karena bahasa Angkola bisa mempertahankan keberadaannya di era globalisasi dewasa ini. 


\section{PENUTUP}

Bentuk borrowing bahasa Arab dalam aqiqah ni daganak tubu berbahasa Angkola lebih cenderung menggunakan adopsi dan adaptasi daripada hibrida dan serapan terjemahan. Hal ini dibuktikan dari kemunculan adopsi sebanyak delapan kata, adaptasi sebanyak delapanbelas kata, sedangan hibrida dan serapan terjemahan tidak ditemukan sama sekali. Berdasarkan analisis sebelumnya, maka dapat dijelaskan bahwa nama Tuhan, sebutan untuk Rasul, nama surat Alquran, pujian untuk Allah, ucapan salam, dan nama orang diadopsi secara utuh tanpa perubahan sedikitpun.

Selanjutnya, penggunaan borrowing bahasa Arab dalam aqiqah ni daganak tubu tidak menyebabkan terjadinya pergeseran pada bahasa Angkola karena borrowing bahasa Arab sangat membantu perkembangan bahasa Angkola. Hal ini karena bahasa Arab dapat melengkapi leksikon dari bahasa Angkola khususnya untuk penggunaan istilah keagamaan.

Mengingat, hanya satu konteks yang dianalisis maka dapat dilihat bahwa kecenderungan bahasa Angkola untuk mengadaptasi sangat tinggi karena perbedaan pelafalan yang mencolok. Adopsi hanya untuk penamaan tertentu yang sudah baku. Hibrida dan serapan terjemahan belum ditemukan. Dengan demikian, bahasa Angkola terus mengalami perkembangan dan mengalami proses dalam melengkapi leksikonnya.

Kemudian, berkat borrowing bahasa Arab, masyarakat Angkola menjadi lebih lengkap leksikonnya dalam berkomunikasi. Kemudian saran untuk penelitian lebih lanjut agar dapat mengeksplorasi lagi kajian borrowing bahasa Arab pada bahasa Angkola dalam konteks yang berbeda. Dengan demikian, bangunan teoretis linguistik, khususnya pada bidang morfologi bahasa Angkola akan semakin lengkap dan pendokumentasian bahasa daerah dapat dilestarikan agar tidak punah ditelan zaman.

\section{DAFTAR PUSTAKA}

Al-kusyairi, M. K. (2015). Nilai-Nilai Pendidikan dalam Hadits Ibadah Aqiqah. Jurnal Al-hikmah, 12(47), 152-162.

Arifin, B. 2010. (2010). Bahasa Bantu. Jakarta: Universitas Terbuka.

Astari, R. et. a. (2014). Bentuk Ortografi Istilah Serapan Bahasa Inggris ke dalam Bahasa Arab. Kawistara, 4(3), 257-270. https://doi.org/10.22146/kawistara.6381

Baumi, G. S. (2007). Burangir Barita. Padangsidimpuan. 
Daulay, Islamail R, \& Manaf, Abdul M. (2013). Nilai-Nilai Edukatif Dalam Lirik Nyanyian Onang - Onang Pada Acara Pernikahan Suku Batak Angkola Kabupaten Tapanuli Selatan Provinsi Sumatra Utara. Jurnal Bahasa, Sastra dan Pembelajaran, 1(3).

Firdaus, W. (2018). Realisasi Pronomina dalam Bahasa Mooi: Analisis Tipologi Morfologi. Ranah: Jurnal Kajian Bahasa, 7(2), 180-193. https://doi.org/10.26499/rnh.v7i2.496

Fitrianor, M. (2015). Nilai-Nilai Pendidikan Islam dalam Pelaksanaan Akikah dan Tasmiah di Kel. Baamang Hulu Kec. Baamang Kab. Kotim. Jurnal Studi Agama dan Masyarakat, 11(1), 23-43. https://doi.org/10.23971/jsam.v11i1.439

Hadi, S. (2017). Pembentukan Kata dan Istilah Baru dalam Bahasa Arab Modern. Arabiyat: Jurnal Pendidikan Bahasa Arab dan Kebahasaaraban, 4(2), 153173. https://doi.org/10.15408/a.v4i2.5801

Hutahuruk, M. (1987). Sejarah Ringkas Tapanuli Suku Batak. Jakarta: Erlangga.

K. Hitti, P. (2002). History of The Arabs Edisi Revisi ke-10. New York: Palgrave McMillan.

Kozok, U. (2009). Surat Batak. Jakarta: Kepustakaan Populer Gramedia.

Kulsum, U. (2015). Sufiks -is dan -ik sertaProblematikanya dalam Bahasa Indonesia. Jurnal Metalingua, 13(2).

Kusuma, Deli, \& Widayati, Dwi. (2015). Keterancaman Leksikon Ekoagraris Dalam Bahasa Angkola/Mandailing: Kajian Ekolinguistik. Kajian Linguistik, 12(1).

Lubis, M. (2011). Suku Angkola. Diambil dari https://untukmengisiwaktuluang.blogspot.co.id/2011/03/suku-angkola.html

Mabruroh, K. (2017). Perubahan Fonetik pada Kata Serapan Bahasa Arab ke dalam Bahasa Jawa dalam Bahasa Harian ( Kajian Analisis Fonologi ). 2(2), 305324.

Mojela, V. M. (2010). Borrowing and loan words: The lemmatizing of newly acquired lexical items in sesotho sa leboa*. Stellenbosch: Buro van die Woordeboek van die Afrikaanse Taal (Bureau of the WAT).

Mualimin. (2015). Nilai-Nilai Pendidikan Islam dalam Aqiqah. Al=Tadzkiyah: Jurnal Pendidikan Islam, 6, 80-92.

Pastika, I. W. (2012). Pengaruh Bahasa Asing terhadap Bahasa Indonesia dan Bahasa Daerah: Peluang atau Ancaman? Jurnal Kajian Bali (Journal of Bali Studies, 02(2013), 141-164.

Poplack, S. (2012). What does the Nonce Borrowing Hypothesis hypothesize? University of Ottawa: Cambridge University Press.

Pulungan, H. R. (2016). Serapan Kosakata Bahasa Arab Mempengaruhi Budaya Islam Batak Angkola-Mandailing. Jurnal Al-Muaddib, 1(1), 1-18.

Qurratulain, A., \& Zunnorain, S. (2015). Acculturation Through Means Of Communication: A Study Of Linguistic Exchanges Between Chinese And Arabic. Trames: A Journal of the Humanities and Social Sciences, 19(1)), 5171.

Rinawidiastuti \& Nursidiq, C. (2017). Ibm UD . H . Suroto dan Madani Aqiqah Penyedia Hewan Kurban, Aqiqah dan Daging Kambing di Purworejo. 239242. 
Roveneldo. (2017). Prosesi Perkawinan Lampung Pepadun: sebagai Bentuk Pelestarian Bahasa Lampung. Ranah: Jurnal Kajian Bahasa, 6(2), 220-234. https://doi.org/10.26499/rnh.v6i2.265

Sa'aida, Z. (2016). Expanding the Lexicon: The Case of Jordanian Arabic. Advances in Language and Literacy Studies, 7(6), 9-14. https://doi.org/10.7575/aiac.alls.v.7n.6p.9

Sahril. (2014). Tradisi Akikah Masyarakat Melayu Pentas Sastra Lokal “ Syair Nyanyian Anak" dalam Kajian Etnopuitika. Jentera, 3(1), 59-71. https://doi.org/10.26499/jentera.v3i1.433

Sahril. (2018). Pergeseran Bahasa Daerah pada Anak-anak di Kuala Tanjung Sumatra Utara. Ranah: Jurnal Kajian Bahasa, 7(2), 210-228. https://doi.org/10.26499/rnh.v7i2.571

Salim, L. (2015). Peranan Bahasa Arab terhadap Ilmu Pengetahuan. Jurnal Adabiyah, 15(2), 168-176.

Santosa, R. (2014). Metode Penelitian Kualitatif Kebahasaan. Surakarta: Universitas Sebelas Maret.

Sari, Y. A., \& Utama, F. (2019). Request and Politeness Strategy by Native Dayanese at OKU South Sumatra Indonesia. International Journal of Applied Linguistics and English Literature, 8(1).

Tadmor, U. (2007). Grammatical Borrowing in Indonesia. Berlin: Walter de Grayter GmbH \& Co. KG. D-10785.

Tatang dan Syihabuddin. (2014). Analisis Tuturan Direktif dan Nilai Budaya pada Buku Al 'Arabiyah Bayna Yadayka. el Harakah, 16(1), 111-129. https://doi.org/10.18860/el.v16i1.2772

Ubaidillah, I. (2013). Kata Serapan Bahasa Asing dalam Al-Qur'an dalam Pemikiran At-thobari. Jurnal At-Ta'dib, 8(1), 119-132. http://dx.doi.org/10.21111/attadib.v8i1.517 